\title{
Globalization and the Limits to Poverty Alleviation ${ }^{1}$
}

by

\author{
Pranab Bardhan \\ University of California at Berkeley
}

(this draft: March 15, 2003)

A raging issue of academic and public debate (that has spilled over into the streets in noisy demonstrations in recent years) concerns the impact of globalization on the wellbeing of the world's poor. Of course, different people mean different things by globalization; some interpret it to mean the global reach of new technology and capital movements, some refer to outsourcing by domestic companies in rich countries, others protest against the tentacles of corporate capitalism. As I see it, a large part of the opposition to globalization relates to its three different aspects:

(a) the fragility of valued local and indigenous cultures of masses of people in the world facing the onslaught of global mass production and cultural homogenization (through global brand-name products, movies, music, fast food, soft drink, internet, etc.);

(b) the devastation caused to fragile economies by billions of dollars of volatile shortterm capital stampeding around the globe in herd-like movements;

(c) the damage caused to jobs, wages and incomes of poor people by the dislocations and competition of international trade and foreign investment and the weakening of the ability of the state to compensate for this damage and in general to alleviate poverty.

\footnotetext{
${ }^{1}$ Thanks, non-implicating, are due to Sam Bowles, Ann Harrison, and Ravi Kanbur for helpful discussion on an earlier draft.
} 
These three issues are inter-related: for example, ethnic handicrafts wiped out by imports of manufactures may be seen as both economic and cultural loss; when short-term speculative capital rushes out of a developing country it inevitably has adverse effects on its medium to long-term investment climate as well. But they are conceptually separable issues. In this paper I shall confine myself to a discussion of issue (c); in other words, I shall mainly interpret globalization to mean openness to foreign trade and long-term capital flows and try to understand the possible difficulties poverty alleviation policies in poor countries may face from such international economic integration. For this understanding we need first to look at the processes by which globalization may affect the conditions of the poor, and then analyze the ways in which the policies meant to relieve those conditions are hemmed in by global constraints. In general I believe that globalization can cause many hardships for the poor but it also opens up opportunities which some countries can utilize and others do not, largely depending on their domestic political and economic institutions, and the net outcome is often quite complex and almost always context-dependent, belying the glib pronouncements for or against globalization made in the opposing camps.

For the record let me say that on the important issues (a) and (b) ignored in the rest of the paper, I am generally in favor of some modest restrictions on the full fury of globalization. On (a) I think there are valid arguments for cultural protection ${ }^{2}$ that even an economist can make: (i) preservation of cultural diversity on the same lines as that for bio-diversity and 'option value' in environmental economics; (ii) intertemporal externality in the form of 'forgetting by not doing' in production of local varieties, on lines similar to the more familiar case of 'learning by doing'; (iii) endogenous preferences, when what we choose depends on the range of varieties available and also when these preferences may be molded by giant international firms selling some standardized products but with large advertisement budgets, etc. On (b) let me point out that much of the financial crisis in developing countries in recent years was initially caused by overexposure to foreign

\footnotetext{
${ }^{2}$ I am currently trying to formalize these arguments in terms of theoretical models in joint work with Cecile Aubert and Jeff Dayton-Johnson.
} 
currency-denominated short-term debts. These, everybody now recognizes, are particularly crisis-prone financial instruments. In most cases there was too little discipline in borrowing before the crises and too much discipline afterward. Many international economists (even those who otherwise support free trade) now believe in the need for some form of control over short-term capital flows, particularly if domestic financial institutions and banking standards are weak, though there are differences on the specific form such control should take and on the assessment of the effects of the rise in the cost of capital this may entail. I also think that it is imperative for the international community to work toward the creation and supervision of some international hedging and insurance institution against the impact of capital flow volatility.

I am also leaving out globalization in the form of international labor flows or more emigration of workers from poor to rich countries. If significant numbers of unskilled workers were allowed entry into rich countries even in limited and regulated doses, a large dent could have been made to world poverty, many times what can possibly be brought about by other forms of international integration ${ }^{3}$, but very few even among people who are concerned about the world's poor seem prepared to entertain this 'radical' idea.

One common cliché in the literature as well as in the streets is that globalization is making the rich richer and the poor poorer. While inequality may be increasing in many countries ${ }^{4}$

\footnotetext{
${ }^{3}$ Walmsley and Winters (2002) have estimated that the global gains from allowing even temporary entry of both skilled and unskilled labor services equivalent to $3 \%$ of workforce in OECD countries will amount to about one and a half times the total gains from merchandise trade liberalization.

${ }^{4}$ Whether world income distribution as a whole is getting more unequal is moot, as hundreds of millions of poor people in large countries like China, India, and Indonesia have improved their living standards in recent years.
} 
(on account of a whole host of factors including globalization), my focus in this paper is on the conditions of those trapped in absolute poverty (measured by some bare minimum standard) in low-income countries. It is not at all clear that the poor are getting poorer everywhere in recent decades when large strides in international economic integration have taken place 5 . A quarter of a century back most of the world's poorest people were concentrated in East, Southeast and South Asia, sub-Saharan Africa and Central America. Since then poverty (percentage of people below some poverty line) has substantially declined in large parts of China, Indonesia, and South Asia, and there also have been significant improvements in other social indicators (like literacy or longevity) in most low-income countries, while poverty has remained stubbornly high in sub-Saharan Africa. But correlation does not imply causation: just as a large decline in poverty in China along with globalization does not necessarily mean a causal relation between them, the same may be the case for the non-decline in Africa. Much of the persistence or even deterioration in poverty in Africa may have little to do with globalization, and more to do with unstable or failed political regimes, wars and civil conflicts which afflicted several of those countries; if anything, such instability only reduced their extent of globalization, as it scared off many foreign investors and traders. Similarly, pro-globalizers point to the fact that wages and (possibly) living standards are often better for the poor in coastal cities in China than in the remote areas in the west cut off from the international economy, or in the Mexican border with the US where the maquiladora are located than in the interior provinces, etc., but again one needs to spell out the causal mechanisms at work to convince anybody.

\footnotetext{
${ }^{5}$ For example, Chen and Ravallion (2002) estimate that the proportion of the total population of the developing countries living in households with consumption expenditure per capita less than about \$1 per day in 1998 (at 1993 purchasing power parity) was 23 per cent ( 25 per cent if one were to exclude China), compared to 28 per cent in 1987. The total number of poor people measured this way was about the same between the two years, about 1.2 billion. Note that the end year 1998 partly includes the impact of the Asian financial crisis. This is, of course, subject to many caveats about measuring poverty in terms of one common dollar standard of poverty for many different countries.
} 
The causal processes through which international economic integration -- of the type (c) of section I-- can affect poverty primarily involve the poor in their capacity as workers and as recipients of public services. Let us first take the case of poor workers. They are mainly either self-employed or wage earners. The self-employed work on their own tiny farms or as artisans and petty entrepreneurs in small shops and firms. The major constraints they usually face are in credit, marketing and insurance, and infrastructure (like roads, power, ports, and irrigation), and government regulations (involving venal inspectors, insecure land rights, etc.). These often require substantive domestic policy changes, and foreign traders and investors are not directly to blame (in fact they may sometimes help in relieving some of the bottlenecks in infrastructure and services and in essential parts, components and equipment). If these changes are not made and the selfemployed poor remain constrained, then, of course, it is difficult for them to withstand competition from large agribusiness or firms (foreign or domestic).

Less-constrained small farms or firms are sometimes more productive than their larger counterparts, and are also sometimes more successful in export markets. Small producers are often heavily involved in exports (for example, coffee producers of Uganda, rice growers in Vietnam, garment producers in Bangladesh or Cambodia). But in exports the major hurdle they face is often due to not more globalization but less. Developed country protectionism and subsidization of farm and food products and simple manufactures (like textiles and clothing) severely restrict their export prospects for poor countries ${ }^{6}$. By estimates of the World Bank the total losses incurred by exporters of textiles and garments on account of these trade barriers amount to more than $\$ 30$ billion and the loss to poor countries from agricultural tariffs and subsidies in rich countries is estimated to be about $\$ 20$ billion. I wish the anti-global protesters of rich countries turned their energies toward the vested interests in their own countries which prolong this protectionism and cripple the efforts of the poor of the world to climb out of their poverty. Pro-poor opponents of NAFTA point out how competition from U.S. agribusiness is destroying the livelihoods of small farmers in Mexico, without being equally vocal about the huge 
farm subsidies in the U.S. (now going to be even substantially larger under the new U.S. farm policy) which are largely responsible for this. U.S. wheat export prices are estimated to be 46 per cent below cost of production, U.S. corn export prices are at 20 per cent below cost, and so on ${ }^{7}$. The average cow in EU gets a government subsidy per year that is nearly twice the per capita income of India.

Another increasingly important barrier to trade many small farmers of developing countries face in world markets is that rich countries now shut out many of these imports under a whole host of safety and sanitary regulations (sometimes imposed under pressure from lobbyists of import-competing farms in those countries). This actually increases the importance of the need for involving rich-country transnational companies in marketing poor-country products. These companies can deal with the regulatory and lobbying machinery in rich countries far better than the small producers of poor countries can and at the same time can provide to consumers credible guarantees of quality and safety. Of course, these companies will charge hefty fees for this marketing service (usually much larger than the total production cost), but the small farmers will usually be better off with them rather than without.

Similarly, it may be very difficult, costly, and time-consuming for small producers of manufactures or services in developing countries to establish brand name and reputation in quality and timely delivery, which are absolutely crucial in marketing, particularly in international markets (much more than comparative costs of production which traditional trade theory emphasizes). This is where multinational marketing chains with global brand names, mediating between domestic suppliers and foreign buyers, can be very helpful for a long time, and paying the high marketing margin they charge may sometimes be worth it. At the same time coordinated attempts on the part of developing countries, with technical assistance from international organizations, to build international quality certification institutions for their products should be a high priority.

\footnotetext{
${ }^{6}$ This is, of course, not to minimize the trade barriers imposed by developing countries on imports of other developing countries.
} 
At the lower end of the value chain, more than 50 developing countries depend on 3 or fewer primary commodities for more than half of their export. Exports of such products are often a curse as well as a blessing for these countries, as their prices fluctuate wildly and as the economy is too dependent on them. As a result of recent cases of elimination of the erstwhile inefficiently-run marketing boards and the dismantling of wasteful stabilization schemes, farmers in many African countries now receive a higher fraction of a more volatile (and in some cases, lower) world market price. International commodity agreements among these countries to control their supply in the world market have not worked very well in the past. For reducing their economic vulnerability there is probably not much alternative to attempts at diversification in production and skill-formation, and gradual movement up the supply chain toward activities with more value addition for the same commodity and arranging at an international level institutions of insurance for farmers in poor countries.

Turning to poor wage earners, the theoretical literature on how international trade affects the absolute level of the real wage of unskilled workers is extremely small relative to the one on wage inequality (which, though an important issue, is not my concern here). I can think of seven types of theoretical mechanisms through which this effect may be significant in developing countries, and this can go either way.

(a) The traditional Stolper-Samuelson mechanism applied to a simple two-country (rich-poor) two-factor (capital-labor) world suggests that the workers in the poor country (presumably having abundant supplies of unskilled labor) having a comparative advantage in products intensive in unskilled labor should benefit from trade liberalization. This is, of course, complicated by the fact that developing countries (say, Brazil or Mexico or Turkey) may import labor-intensive products from even poorer countries (say, China or

\footnotetext{
${ }^{7}$ See, for example, the recent Oxfam Report, Rigged Rules and Double Standards: Trade, Globalization, and the Fight against Poverty, 2002.
} 
Indonesia or Bangladesh), so that trade even in terms of this mechanism may lead to lower wages in the former set of developing countries ${ }^{8}$.

(b) If some factors of production are intersectorally immobile, and some goods are non-traded, real wage of an unskilled worker in a poor country may not go up with trade liberalization even in an otherwise standard model of trade theory. Take a three-good model in a hypothetical African country: one is a non-tradable good (say, a subsistence food crop), is largely grown by women who for various social and economic reasons cannot move to other sectors, another good (say, an exportable tree crop) produced largely by men in a capital-intensive way (maybe simply because tree crops lock up capital for a long period), and the third good is an importable (say, processed food) which is somewhat substitutable in consumption for the subsistence food. In this three-sector model it is not difficult to show that the real wage of women may go down when the importable processed food is made cheaper by trade liberalization (under the condition that the elasticity of substitution in consumption of the two foods is sufficiently high).

(c) Take a two-period model where labor on a long-term contract is trained in the first period and this training bears fruit in the second period, when these long-contract workers are more productive than untrained short-contract casual laborers. If opening the economy increases the competition and the probability of going out of business, employers may go more for short-contract and less productive and lower-wage laborers, bringing down the average wage. By a similar reasoning a firm may have less incentive in an open economy to invest in developing a reputation for fairness in wage payments.

(d) On the other hand, increased foreign competition may lead to exit of old inefficient firms and entry of new more efficient firms, or a better allocation of resources within

\footnotetext{
${ }^{8}$ See Wood (1997).
} 
existing firms - this may lead to a rise in average wages in industries that attain such productivity gains 9 .

(e) If firms facing more foreign competition and pressure to reduce costs outsource activities to smaller firms or household enterprises in the informal sector ${ }^{10}$, the average wage (of those formerly employed in the formal sector) may go down, but this need not impoverish workers in general if the poorer informal workers get more employment this way.

(f) If technical change in rich countries is biased against the services of unskilled labor (for which there is plenty of evidence) and if globalization means their impact reaches remote corners of the world, then again employment and wage of unskilled labor in poor countries will go down, as has been reportedly the case, for example, with global tenders to construction companies like Bechtel using labor-saving technology rendering many construction workers unemployed in India.

(g) As foreign competition (or even the threat of it) lowers profit margins, the old rent-sharing arrangements between employers and unionized workers come under pressure. Rents decline both for capital and labor, but labor may have to take a larger cut if, as has been argued, the increase in the (perceived) elasticity of demand in the product market (due to opening of the economy to trade and foreign investment) leads to an increase in the elasticity of demand for labor, lowering its bargaining power and generally weakening unions ${ }^{11}$. This may lead to lower wages, and, sometimes more important,

\footnotetext{
9 The positive link between trade liberalization and productivity has been found in Chile, Colombia, Cote d'Ivoire, Brazil, India and South Korea. One of the most careful micro-studies on this question is by Pavcnik (2002), who finds that massive trade liberalization in Chile in the late 1970's and early 1980's led to growth of productivity at the plant level at the average rate to 3 to 10 per cent. For the other country studies see the references in Pavnick (2002).

${ }^{10}$ Attanasio, Goldberg and Pavcnik (2002) find some evidence that the increase in the size of the informal sector in Colombia towards the end of the 1990's is related to increased foreign competition.

${ }^{11}$ See Currie and Harrison (1997), Rodrik (1997), Leamer (1998) and Reddy (2001). The theoretical relation between product market demand elasticity and the elasticity of derived demand for labor is somewhat more
} 
increased risk of unemployment. Scheve and Slaughter (2002) show how globalization of production through multinational enterprises in particular and related trade can make labor demand more elastic (through increased product market competition and substitution of foreign factors of production including intermediate inputs for domestic factors) and thereby raise economic insecurity for workers.

III

Now let us briefly discuss the empirical evidence on the effect of foreign trade and investment on the wages of unskilled labor in developing countries. The micro evidence on this is rather limited (I am ignoring the usual, flawed, cross-country regressions). More often than not you are cited data on correlations, not a careful empirical analysis of the causal process. For example, the critics of NAFTA will readily point to the decline in real wages of unskilled workers in Mexico in the few years immediately after NAFTA came into operation, overlooking the fact that much of the decline may be due to the peso crisis that engulfed Mexico in this period, which had very little to do with the opening of trade with North America. It is important to disentangle the effects on wages of trade reform from those flowing from macroeconomic policy changes or other on-going deregulatory reforms and technological changes.

On the whole, the labor market effect of trade liberalization in developing countries on the basis of the few micro-econometric studies is rather mixed and quantitatively small. Analyzing a set of 25 trade liberalization episodes in developing countries, using

complex than usual in the case of imperfect competition is not always clear-cut. The empirical evidence in developing countries on the trade-induced changes in the elasticity of demand for labor is rather scanty. Fajnzylber, Maloney and Ribeiro (2001), on the basis of plant-level data and taking both incumbent and exiting or entering firms into account, find in Chile and Colombia very ambiguous effects of trade liberalization on wage elasticities. 
internationally comparable sectoral labor data, Seddon and Wacziarg (2002) come to the conclusion that trade liberalization has far smaller effects on intersectoral reallocation (even at the 3-digit level within manufacturing) than is conventionally presumed. What is more likely is that much of the structural change is intrasectoral and that some of the potential changes are neutralized by policies like exchange rate depreciation, labor regulations, and sector-specific subsidies. The micro-studies of effects of trade reform in Mexico and Morocco by Revenga (1997), Feliciano (2001), and Currie and Harrison (1997) attribute the small effect on employment to labor regulations or to the firms adjusting to trade reform by reducing their formerly protected profit margins and raising productivity rather than laying off workers.

Goldberg and Pavcnik (2001), on the basis of panel data from the Colombian National Household Survey over 1985-94, look at the effect of trade policy on industry wage premiums, i.e., the part of wages that cannot be explained by worker or firm characteristics. They find that the two most protected sectors in Colombia were textiles and apparel, and wood and wood product manufacturing, that are relatively unskilled labor-intensive sectors, and with industry fixed effects trade protection is found to increase industry wage premiums. This is quite consistent with traditional trade theory, particularly when one keeps in mind that such protection of labor-intensive industries in developing countries may be against imports from even more labor-abundant countries, as we have noted in our theoretical mechanism (a) above.

Even when poor unskilled workers lose from trade liberalization in such contexts, it may be possible to combine a policy of trade liberalization with a domestic policy of compensating the losers at low cost. Harrison, Rutherford, and Tarr (2003) have used a computable general equilibrium model for Turkey to show with a numerical exercise that a direct income subsidy to the losers of trade reform, financed by a VAT, is quite costeffective. The main problem, of course, is that of credible commitment on the part of the ruling politicians that losers will be compensated. Recent history in many countries is full of reneged promises on the part of governments to displaced workers. Obviously, this is a 
particularly important matter in poor countries where there is very little effective social protection available from the state. Rich countries have better social safety nets and some programs in place helping displaced workers to adjust (like the federal adjustment assistance program in the US). International organizations that preach the benefits of free trade should take the responsibility of funding and facilitating such adjustment assistance programs in poor countries that can help workers in coping with job losses and getting retrained and redeployed. Until issues of general economic security for poor workers in developing countries is satisfactorily resolved, globalization is bound to raise anxiety and hostility among workers worried about their job security. It is also not a coincidence that countries that have a better record in building institutions of conflict management and coordination have coped better with the dislocations brought about by international trade: the major example is the case of Scandinavian countries where in spite of a strong tradition of organized labor movement and worker solidarity over many decades of the last century, the unions there in general have been in favor of an open economy.

Let us now briefly turn to the case of the poor as recipients of public services. In the lowincome developing countries the poor, particularly those who are in the preponderant informal sector, do not receive much of effective social protection from the state (which makes them particularly vulnerable in case of job displacement brought about by international competition), but the public sector is usually involved in basic services like education and health and public works programs. Cuts in public budgets on these basic services are often attributed to globalization, as the budget cuts to reduce fiscal deficits often come as part of a package of macro-economic stabilization prescribed by international agencies like the IMF. I agree with a common characterization of some of the IMF conditionalities on a crisis-affected country as analogous to medieval ways of trying to cure a patient by blood-letting. But one should keep in mind that the fiscal deficits in these poor countries are often brought about in the first place more by domestic profligacy in matters of subsidies to the rich, salaries for the bloated public sector or military extravaganza. Faced with mounting fiscal deficits, the governments often find it politically easier to cut the public expenditures for the voiceless poor, and that is 
primarily due to the domestic political clout of the rich who are disinclined to share in the necessary fiscal austerity, and it is always convenient to blame an external agency for a problem that is essentially domestic in origin.

The low quality and quantity of public services like education and health in poor countries is not just due to their relatively low share in the public budget. To a large extent even the limited money allocated in the budget does not reach the poor because of all kinds of top-heavy administrative obstacles and bureaucratic and political corruption $^{12}$. Again this is a domestic institutional failure, not largely an external problem. The major effort required here is to strengthen the domestic institutions of accountability.

Finally, let us take up the general issue of possible loss of national policy options relevant for the poor brought about by a developing country's participation in international trade and investment. First of all, I agree with the anti-global protesters that many of the international organisations that define the rules of this order are accountable more to the corporate and financial community of rich countries than to the poor and that the decision-making processes in these organizations need to be much more transparent and responsive to the lives of the people their decisions crucially affect ${ }^{13}$. At the same

\footnotetext{
${ }^{12}$ To give just one instance of a rough magnitude of the problem, the World Bank recently estimated that of the total non-salary budget sanctioned by the central government in Uganda in the period 1991-95 for schools only about 13 per cent actually reached them.

13 The protesters' demand for the abolition of the WTO is, however, misplaced. If the alternative to a multilateral organization like the WTO is for a developing country to face the US in bilateral trade negotiations, the US is likely to be much more dominant and arbitrary in such negotiations than in the dispensations of the WTO (which in its arbitration decisions has sometimes ruled against the US position). It is also to be noted that in the WTO each member country has one vote (the convention is to reach decisions by 'consensus', as the protracted delay caused by one developing country in the agreement among ministers in the recent meeting at Doha shows), whereas in the Brettonwood institutions (IMF and
} 
time it should be pointed out that the protesters in rich countries often speak in the name of the world's poor but support policies which sometimes may actually harm them (more on this below).

Coming to the issue of a government's fiscal options in a global economy, many people are of the opinion that the scope for taxing capital to raise revenue is severely limited by the threat of capital flight in the long run, even if we ignore the problem of short-term speculative capital flows. (In fact capital itself does not have to flee the country; quite often accounting practices, through strategic bookkeeping adjustments, allow the base for capital taxes to migrate even when capital itself does not). While this limitation can be serious, one should not exaggerate its effects. Most countries collect only a small part of their revenues from capital taxation, even in relatively closed economies. In any case there are strong arguments for funding redistributive policies through progressive consumption taxes (say, VAT) rather than taxes on capital or labor. Of course there is a need for tax coordination across countries, and there is some evidence that capital taxation is declining and also converging across countries. But again, one should not overstate this. Even in the highly integrated European Union corporate tax rates have substantially converged not to zero, as some people anticipated, but to about 35 per cent. In general between two equilibria, one with high taxes and high public goods provision and the other with low taxes and low public goods, capital need not choose the latter over the former.

Serious obstacles to redistributive policies are often domestic. At the micro-level of firms, farms, neighbourhoods and local communities there is scope for a great deal of efficiencyenhancing egalitarian measures that can help the poor and are not primarily blocked by the forces of globalization. Various asset redistribution and poverty alleviation policies (like

the World Bank) voting is dollar-weighted. But there is no denying the fact that the rich countries (and their large corporate lobbies) exercise a dominant effect on the agenda-setting and decision-making of the WTO, as with the Brettonwood institutions. At the Doha meeting there have been some welcome signs of a slow opening of the process to the developing countries. But serious efforts are needed to strengthen the technical negotiation capacity of poor countries in international trade forums where they face the wellequipped and well-funded teams of lawyers and negotiators representing rich countries. 
land reform, expansion of education and health facilities for the poor, making available guaranteed public works programs as a last resort for the unemployed, organising cooperative and peer-monitored credit and marketing for small firms and farms, facilitating formation of local community organizations to manage the local environmental resources, etc.) can improve productive efficiency and expand opportunities for the poor, and yet may be within the range of capability of domestic institutions of the community and the polity. The main hindrance in devoting substantial fiscal and organizational resources to these projects is the considerable opposition from domestic vested interests-- landlords, corrupt and/or inept politicians and bureaucrats, and the currently subsidized rich. Closing the economy does not reduce the power of these vested interests. If anything, the forces of competition unleashed by international integration may reduce their monopoly power.

An area where more empirical work needs to be done in poor countries is on this question of comparative market structure with or without an open economy. On the one hand, an open economy is likely to be more 'contestable' (with even monopoly sellers facing more threats of potential entry) than an economy where domestic sellers are sheltered from foreign competition. On the other hand, the giant transnational companies with deep pockets can afford to resort to predatory pricing vis-à-vis smaller domestic sellers, particularly in industries where economies of scale and other such entry barriers are important. One can only note that over the years competition among transnationals in international markets has increased. In general it is not clear if domestic consumers (and workers) always prefer domestic monopolists to foreign ones. Some may prefer to be exploited by Citibank rather than by the local loan shark.

It is true that the monopoly marketing chains, like those we have referred to earlier, eat up a large part of the gains from trade that form the staple of international economics textbooks. Just to cite one example, even today long after the infamous days of the reign of the United Fruit Company, in Ecuador the local producer gets only $\$ 2$ or $\$ 3$ for each 43-lb box of bananas sold by the marketing chains in US or Europe for about $\$ 25$. But the 
important question here is what the counterfactual is. The trade economists state that the alternative scenario of no trade is worse for the poor banana grower. The activistprotesters suggest that the monopolist transnational marketing company should keep lower margins. They should then agitate more for anti-trust action, not anti-trade action. Otherwise their protests often end up merely strengthening the hands of protectionists of rich countries. Faced with this the producers in poor countries have to ask themselves essentially the trade economists' counterfactual: yes, we know the world is unfair, but can we do any better by closing down our economy? But this also means there should be energetic international attempts to certify codes against international restrictive business practices and to establish, as the Oxfam Report (referred to earlier) recommends, an antitrust investigation agency, possibly under WTO auspices.

Trade economists usually do not consider the possible impact of international operations on the domestic political equilibrium. Large transnational companies, working through the rich country governments and with their threats of financial withdrawal, can sometimes shift the political equilibrium particularly in small countries and weak states, although it has to be noted that crass manipulations and 'gunboat diplomacy' of the past are getting somewhat more difficult than before. Others suggest that in countries with some established political and bureaucratic structures the internationally exposed sector if it becomes better-off may undermine older alliances that may have retarded economic progress. We need more systematic empirical studies of how opening the economy may change the nature of politics in a developing country, controlling for other factors. There is some evidence ${ }^{14}$ that in Mexico the post-NAFTA exposure to international trade helped in bringing about the erosion of support for the long-dominant and corrupt ruling party (PRI). The mechanisms that are involved or if they work at all in forging political coalitions and institutions that may ultimately help the poor are likely to vary from one country to another.

${ }^{14}$ See A. Diaz-Cayers, B. Magaloni, and B.R.Weingast (2000). 
While the transnational companies may have deeper pockets and larger political clout visà-vis the poor unskilled laborers of a country, there is very little evidence that the latter get lower wages and fewer jobs in the presence of those companies, compared to what they will get in their absence, other things remaining the same. Contrary to the impression created by the campaign in affluent countries against 'sweatshops' run by transnational companies in poor countries, it can be pointed out that the poor are often banging at the gates of these sweatshops for a chance of entry, since their current alternative is much worse, in inferior occupations or work conditions or in unemployment.

Here again there is a clash of counterfactuals between the two sides of the debate. The protesters say (at least implicitly) that Nike wage may be higher than the wage in the vast hinterland from which streams of poor workers come, but it is lower than what it would be if Nike's (monopsonist) profits were lower. The trade economists say that if there were no Nike, the wage would revert to the low hinterland wage, and some of them also implicitly deny the existence of the (local) monopsony, and so presume that the implementation of a minimum ('fair') wage will push some of the workers to the hinterland. Clearly there is a need here for good empirical projects to investigate the nature of the labor markets facing international firms like Nike in poor countries. In their absence, one wonders how applicable the standard argument for minimum wage given by progressive labor economists and sociologists in the context of a monopsonist employer is to the current problem. The monopsony power of Nike would imply that if Nike tries to hire more workers from the hinterland it will drive up the marginal cost of labor against itself. If one believes instead that there is an almost 'unlimited' supply of hinterland labor 'banging at the gates', then the marginal and average cost of hiring labor for Nike should not be very different, and so the usual argument that a minimum wage will not reduce employment under monopsony should not apply here.

Similarly, for those who complain about the exploitation of young women in the garment factories of transnational companies do not often appreciate the relative improvement in the conditions and status of these women (say, in the garment industry in Bangladesh or 
Mauritius) compared to the alternatives otherwise available to them. This is not an argument against efforts to improve their work conditions (and certainly not in favour of the totally indefensible cases of forced labor or hazardous or unsafe work conditions ${ }^{15}$ ), but it is an appeal for looking at the reality of the severely limited opportunities faced by the poor and the unintended consequences of trying to restrict rich-country imports of 'sweatshop' products in terms of the harm it causes to the displaced poor workers.

A similar argument applies to the case of child labor. Simply banning imports of products that have used child labor is likely to send the children often not to schools but to much inferior occupations in the usually much larger non-traded sector ${ }^{16}$. (In India, for example, an estimated 95 per cent of child workers are in the non-traded sector anyway). In Vietnam a quarter of all children work in agriculture. From 1993 to 1997 the government gradually relaxed its rice export quota, which led to rice producers getting a better price. Using the Vietnam Living Standards Survey data for a panel of 4000 households in this period, Edmonds and Pavcnik (2001) estimate that this better price received for rice can account for almost half of the decline in child labour that took place in this period. Here is a case of increased earning opportunities from participation in the international market with a product that is intensive in child labor led to its decline. A policy of trade sanctions against Vietnamese rice, with the apparent good intention of reducing child labor in its production, could have the opposite effect.

\footnotetext{
${ }^{15}$ Conceptually, one should distinguish between unsafe or hazardous work conditions and forced labor on the one hand and low-wage jobs on the other. Under capitalism just as workers willing to sell themselves as serfs are not permitted, unsafe work conditions that can cause bodily injury are to be strictly regulated. That is the reason why they are part of the ILO core labour standards that have been ratified by most countries. But the case for stopping workers from accepting low-wage jobs is much weaker.

${ }^{16}$ In 1993 Senator Tom Harkins in the US Congress brought a bill to ban imports of products using child labor. It was not passed subsequently, but almost immediately after the introduction of the bill the garment industry in Bangladesh dismissed between thirty to forty thousand children it formerly employed. In 1996 OXFAM carried out a survey to find out what had happened to these children. It was found that (with the concerted effort of some education NGO's) about ten thousand children did go back to school, but the rest went to much inferior occupations, including child prostitution.
} 
Clearly, taking mainly a legal or regulatory approach (like simply banning child labor or boycotting their produce) to achieve an otherwise laudable social goal is the wrong way to go about it. Unintended consequences abound, and the solutions are often a little more complex than the simplistic remedies proposed by some activists. The widely noted program in Mexico, PROGRESA, of paying a subsidy to the mother conditional on her children's school attendance has made a significant dent on child labor. The program (now under a different name) has expanded substantially in Mexico, and NAFTA or global integration has not come in the way. It is also important to understand the need for coordinated action among the different parties involved. A good example is the Partners' Agreement to Eliminate Child Labor in the Soccer Ball Industry in Pakistan in the mid1990 's, by which the transnational sporting goods companies (involved in production in the city of Sialkot in Pakistan of a large fraction of the world supply of soccer balls), the local government and some NGO's reached an agreement to eliminate child labor in that industry, provide scholarships to the displaced children, and to arrange the school facilities needed, and to monitor the agreement. Such coordination programs if they can involve all the different parties involved (including the small producers), rather than trade boycotts or exogenously imposed 'codes of conduct', are likely to be much more effective and equitable.

\section{$\mathrm{V}$}

Environmentalists argue that trade liberalization damages the poor by encouraging overexploitation of the fragile environmental resources (forestry, fishery, surface and groundwater irrigation, grazing lands, etc.) on which the daily livelihoods of particularly the rural poor crucially depend. Here also the answers are actually complex and mere trade restriction is not the solution. The environmental effects of trade liberalization on the rural economy depend on the crop pattern and the methods of production. Take, for example, an African rural economy where the exportable product is a capital-intensive 
tree crop (like coffee or cocoa), the import-substitute is a land-intensive crop (like maize), and there is a labor-intensive subsistence (non-traded) crop (like roots and tubers). The economy may have a comparative advantage in tree crops. In this case an increase in import substitution leads to an expansion of cultivated land under the land-intensive crop as well as a shortening of the fallow period, leading to depletion of natural vegetation and biomass. Trade liberalization in this context, through encouraging the production of the less land-intensive tree crop, can significantly improve the natural biomass, as has been shown by Lopez (2000) for Cote d'Ivoire in the latter part of the 1980's, using the data from the Living Standards Survey and some remote sensing data from satellite images.

One reason why land-intensive crops may lead to overuse of land and depletion of natural vegetation (or that expansion of the agricultural frontier in general leads to deforestation) is the lack of well-defined property rights or lack of their enforcement in public or communal land. In such cases private cost of expanding production is less than the social cost and there is overuse and degradation of environmental resources. If the country exports such resource-intensive products, foreign trade may make this misallocation worse. International trade theorists point out that trade restriction is not the first-best policy in this situation, correcting the property rights regime is. But the latter involves large changes in the legal-regulatory or community institutional framework which take a long time to implement, and given the threshold effects and irreversibilities in environmental degradation (a forest regeneration requires a minimum stock, for example), one may not afford to wait. In that case some program of (time-bound) trade restriction coupled with serious attempts at the overhaul of the domestic institutional framework may be necessary. In other cases domestic policy changes can be implemented much more quickly, and restricting trade is unnecessary and undesirable. For example, administered underpricing of precious environmental resources (irrigation water in India, energy in Russia, timber concessions in Indonesia, etc.) is a major cause of resource depletion and correcting it should not take much time. Domestic vested interests, not globalization, are responsible for the prolongation of such socially damaging policies. 
In the case of some resource-intensive exports it is difficult for a country by itself to adopt environmental regulations if its international competitors do not adopt them at the same time and have the ability to undercut the former in international markets. Here again there is an obvious need for coordination, in the environmental regulation policies of the countries concerned. Given the low elasticity of demand for many resource-intensive primary export commodities from developing countries in the world market, such coordinated policies, while raising prices and the terms of trade need not lead to a decline in export revenue.

Finally, I largely agree with many protester/activists on the issue of TRIPs (trade related intellectual property rights). This was brought within the WTO purview under considerable US pressure and developing countries reluctantly went along in exchange for the promise (partly and sometimes covertly defaulted on by now) of substantial reductions in protection of textiles and farm products by rich countries. A World Bank study estimates that the TRIPs arrangement is to raise the revenue of 6 rich countries by about $\$ 40$ billion. One can imagine the increased burden, for example, on private households and public health programs in poor countries as the protected drug prices rise under TRIPs. For many products the cited justification of patents in terms of keeping incentives alive for new research does not warrant the rapacious monopoly pricing for a prolonged period (the patent life in the rest of the world was raised under TRIPS to the US standard of 20 years). Even when the original patent tends to run out, the transnational company holding the patent often has various ways of effectively extending it (by slightly changing the composition of ingredients in the product), bribing or intimidating the potential producers of the generic substitute, and through high-pressure advertisement keeping many of the customers hooked on to the original brand. In some cases the patent holder privately appropriates the benefits of publicly funded research. In other cases private companies are patenting in rich countries plant genetic and other resources collected from poor countries, the uses for which have been part of the common knowledge pool of communities for centuries. It is also recognized now by many scientific researchers that existing patents often act as an obstacle to further research that 
tries to build on earlier findings (in developing countries this includes research for adapting new technology to the special conditions there).

The problem of international patents in life-saving drugs in poor countries recently caught public attention in connection with the controversies about the prices of anti-retroviral drugs for AIDS patients in Africa. That case showed how the transnational pharmaceutical companies kept on threatening action (until they had to relent under international public pressure) against poor countries even when the latter were only trying to adopt measures (like 'compulsory licensing' and 'parallel imports') that are deemed legitimate in national public health emergencies under existing WTO rules. The hypocrisy of the US government on this issue became particularly blatant when during the anthrax scare in end-2001 it announced that it would refuse to pay high prices to Bayer, the company that produces an anti-anthrax drug. The Trade Representative of the same government had threatened trade sanctions against developing countries for trying to do similar things in their medical emergencies.

The major problem in corporate drug research is that only a tiny fraction of what the companies spend on finding new diet pills or anti-wrinkle creams is spent on drugs or vaccines against the major killer diseases of the world, like malaria or T.B. Since these diseases kill millions of people (many of them children) mainly in countries with low purchasing power, the transnational pharmaceutical companies are less interested. There are now the beginnings of some international attempts to make credible arrangements on the part of international organizations like WHO and the World Bank in collaboration with NGO's like Medicins sans Frontiers, private Foundations (like the Gates Foundation) and donor agencies and local governments to a commitment ${ }^{17}$ to purchase vaccines to be developed by transnational companies against some of the killer diseases. This is another major example of how international coordination and public-private partnerships can be vital in resolving complex international problems. For other diseases

${ }^{17}$ For a discussion of the relevant incentive issues in vaccine research and ways of improving credibility of purchase commitment, see M. Kremer, "Creating Markets for New Vaccines", Innovation Policy and the Economy, 2001. 
(like diabetes or cancer) which kill large numbers of people in both rich and poor countries the incentive argument for enforcing patents in poor countries is weak, since that research will be carried out by the transnational drug companies in any case as the market in rich countries is large enough (provided resale can be limited) ${ }^{18}$.

In general while globalization in the sense of opening the economy to trade and long-term capital flows can constrain some policy options and wipe out some existing jobs and entrepreneurial opportunities for the poor and for small enterprises, in the medium to long run it need not make the poor much worse off, if appropriate domestic policies and institutions are in place and appropriate coordination among the involved parties can be organized. If the institutional prerequisites can be managed, globalization opens the door for some new opportunities even for the poor. Of course, domestic institutional reform is not easy and it requires political leadership, popular participation and administrative capacity which are often lacking in poor countries. One can only say that if we keep the focus on agitating against transnational companies and international organizations like the WTO, attention in those countries often gets deflected from the domestic institutional vested interests, and the day of politically challenging them gets postponed. In fact in some cases opening the economy may unleash forces for such a challenge.

As in the debates several decades back around 'dependency' theories, there is often a tendency to attribute much of the problems of underdevelopment to the inexorable forces of the international economic and political order, ignoring the sway of the domestic vested interests. In many countries poverty alleviation in the form of expansion of credit and marketing facilities or land reform or public works programs for the unemployed or provision of education and health need not be blocked by the forces of globalization. This,

${ }^{18}$ Lanjouw (2002) has suggested a small change in the administration of patent laws in rich countries, that forces pharmaceutical companies to choose between patent protection in rich countries and protection in a designated list of poor countries. This will make them give up protection in those poor countries for drugs against global diseases since the larger market is in rich countries, while preserving the vast majority of patent incentives. 
of course, requires a restructuring of existing budget priorities and a better and more accountable political and administrative framework, but the obstacles to these are often largely domestic (particularly in countries where there are some coherent governance structures in place). In other words, for these countries, globalization is often not the main cause of their problems, contrary to the claim of critics of globalization; just as globalization is often not the main solution of these problems, contrary to the claim of some gung-ho free traders.

All this, of course, does not absolve the responsibility of international organizations and entities in helping the poor of the world, by working toward a reduction of rich-country protection on goods produced by the poor, by energetic anti-trust action to challenge the monopoly power of international (producing and trading) companies based in rich countries, by facilitating international partnerships in research and development of products (for example, drugs, vaccines, crops) suitable for the poor, and by organizing more substantial (and more effectively governed) financial and technology transfers and international adjustment assistance for displaced workers, and help in (legal and technical) capacity building for poor countries in international negotiations and quality certification organizations. Globalization should not be allowed to be used, either by its critics or by its proponents, as an excuse for inaction on the domestic as well as the international front when it comes to the matter of relieving the poverty that oppresses the life of billions of people in the world. 


\section{REFERENCES}

Attanasio, O., P.K.Goldberg, and N. Pavcnik (2002). "Trade Reforms and Wage Inequality in Colombia", unpublished.

Chen, S., and M. Ravallion (2002), "How Did the World's Poorest Fare in the 1990's", Review of Income and Wealth, forthcoming.

Currie, J., and A. Harrison (1997)."Sharing the Costs: The Impact of Trade Reform on Capital and Labor in Morocco", Journal of Labor Economics, 15 (3): S44-S71.

Diaz-Cayers, A., B. Magaloni and B.R. Weingast (2000), "Democratization and the Economy in Mexico: Equilibrium (PRI) Hegemony and its Demise", unpublished, Stanford and UCLA.

Edmonds, E., and N. Pavcnik (2001). "Does Globalization Increase Child Labor? Evidence from Vietnam", unpublished, Dartmouth College.

Fajnzylber, P., W.F. Maloney, and E. Ribeiro (2001). "Labor Demand and Trade Reform in Latin America", unpublished, World Bank, Washington D.C.

Feliciano, Z.M. (2001). "Workers and Trade Liberalization: The Impact of Trade Reforms in Mexico on Wages and Employment", Industrial and Labor Relations Review, 55(1): 95-115.

Goldberg, P., and N. Pavcnik (2001). "Trade Protection and Wages: Evidence from Colombian Trade Reform", unpublished.

Harrison, G. W., T. F. Rutherford, and D. G. Tarr (2003). "Trade Liberalization, Poverty and Efficient Equity", Journal of Development Economics. 
Lanjouw,J.O.(2002), "A Patent Policy for Global Diseases: U.S. and International Legal Issues", Harvard Journal of Law and Technology,vol 16(1).

Leamer, E.E. (1998). "In Search of Stolper-Samuelson Linkages between International Trade and Lower Wages", in S. M. Collins (ed.), Imports, Exports, and the American Worker, Washington, D.C.: The Brookings Institution Press:141-202.

Lopez, R. (2000). "Trade reform and environmental externalities in general equilibrium: analysis for an archetype poor tropical country", Environment and Development Economics 4(4): 337-404.

Pavcnik, N. (2002). "Trade Liberalization, Exit and Productivity Improvements: Evidence from Chilean Plants", The Review of Economic Studies 69(1):245-76.

Reddy, S. (2001). "Liberalization, Distribution and Political Economy", unpublished, New York: Barnard College.

Revenga, A. (1997). "Employment and Wage Effects of Trade Liberalization: The Case of Mexican Manufacturing", Journal of Labor Economics, 15 (3): S20S43.

Rodrik, D. (1997). Has Globalization Gone Too Far? Washington D.C.: Institute of International Economics.

Seddon, J. and R. Wacziarg (2002). "Trade Liberalization and Intersectoral Labor Movements", unpublished, Stanford.

T. Walmsley and A. Winters (2002). "Relaxing Restrictions on the Temporary Movement of Natural Persons" A Simulation Analysis", GTAP Resource Center Paper no. 949, Purdue University. 
Wood, A. (1997). "Openness and Wage Inequality in Developing Countries: The Latin American Challenge to East Asian Conventional Wisdom", World Bank Economic Review 11(1):33-57. 